\title{
Macrocystis integrifolia and Lessonia trabeculata (Laminariales; Phaeophyceae) kelp habitat structures and associated macrobenthic community off northern Chile
}

\author{
Mario J. Villegas · Jürgen Laudien • \\ Walter Sielfeld · Wolf E. Arntz
}

Received: 6 June 2007 / Revised: 2 November 2007 / Accepted: 9 November 2007 / Published online: 20 December 2007

(C) Springer-Verlag and AWI 2007

\begin{abstract}
Macrocystis integrifolia and Lessonia trabeculata form vast kelp beds providing a three-dimensional habitat for a diverse invertebrate and fish fauna off northern Chile. Habitat modifications caused by the El Niño Southern Oscillation (ENSO) are likely to alter the inhabiting communities. The aim of this study was to reveal relationships between distinct habitat structures of a $M$. integrifolia kelp bed, a dense L. trabeculata kelp bed and L. trabeculata patches colonizing a barren ground, and the associated dominant macrobenthic key species. Seasonally 15 sampling units $\left(10 \mathrm{~m}^{2}\right.$ each) of any of the three habitats were monitored by SCUBA divers, which counted sporophytes and macroinvertebrates living between the latter. Furthermore, samples of plants were analysed in the laboratory to measure the morphological variables: total plant length, maximal holdfast diameter, stipe number, number of dichotomies per stipe, frond width and total drained wet mass. Multivariate analysis showed that the L. trabeculata kelp bed is denser, with a higher number of dichotomies per stipe, whereas sporophytes of $M$. integrifolia are longer with more stipes and wider fronds. Sporophytes of $L$. trabeculata patchily

Communicated by Sven Thatje.
\end{abstract}

Special Issue: Climate variability and El Niño Southern Oscillation:

implications for natural coastal resources and management. S. Thatje (ed.)

M. J. Villegas $(\bowtie) \cdot$ W. Sielfeld

Departamento de Ciencias del Mar,

Universidad Arturo Prat, Casilla 121, Iquique, Chile

e-mail: mario.villegas@unap.cl

J. Laudien · W. E. Arntz

Alfred Wegener Institute for Polar and Marine Research,

P.O. Box 120161, 27515 Bremerhaven, Germany

e-mail: Juergen.Laudien@awi.de

W. E. Arntz

e-mail: Wolf.Arntz@awi.de present on barren ground are shorter and have more stipes compared with those in the dense L. trabeculata kelp bed. Thus, the habitats provide different three-dimensional structures. The associated macrobenthic communities show a variable degree of overlapping; however, key faunal assemblages were distinguished for each habitat. Our study provides evidence that habitat diversity drives species diversity, the more homogeneous, monospecifically composed kelp bed habitats show comparatively low diversity, mainly caused by the dominance of the ascidian P. chilensis and $T$. tridentata in the M. integrifolia bed, and the mussel A. ater only present in the $L$. trabeculata bed. Species richness and diversity is highest in the heterogeneous habitat where $L$. trabeculata patches interrupt the barren ground. Our study revealed morphological differences between $M$. integrifolia and $L$. trabeculata kelp beds reflected in stipe number, plant length, dichotomies per stipe, and wet mass, which influence the composition of the associated characteristic fauna and its functional relations i.e. T. niger and T. tridentata.

Keywords Habitat structure - Lessonia trabeculata . Macrobenthic community $\cdot$ Macrocystis integrifolia . Predator-herbivore-kelp interactions

\section{Introduction}

The kelp Macrocystis integrifolia Bory 1826 and Lessonia trabeculata Villouta \& Santelices 1986 are the two characteristic species of Laminariales in shallow hard-bottom habitats off northern Chile. Both species have biphasic heteromorphic life cycles, with a short-lived microscopic gametophytic generation alternating with a long-lived macroscopic perennial sporophytic generation (Hoffman and Santelices 1997; Buschmann et al. 2004; Tala et al. 2004). 
They form vast kelp beds that provide a three-dimensional habitat structure inhabited by a diverse invertebrate and fish fauna (Vásquez 1992; Vásquez et al. 2001; Sielfeld et al. 2002; Vega et al. 2005; Pérez 2006). The structure of these kelp beds is physically controlled by variations in upwelling and alternating oceanographic events such as El Niño (EN) and La Niña (LN) - the warm and cold phase of the El Niño Southern Oscillation (ENSO) (Vásquez and Vega 2004; Arntz et al. 2006; Vásquez et al. 2006). During El Niño (e.g. 1997/98) mass mortalities of kelp and benthic carnivores such as sea stars were recorded and related to the high coastal water temperatures off Peru $\left(16^{\circ} \mathrm{S}\right)$ (Fernández et al. 1999). In contrast, mass mortalities were not reported from northern Chile $\left(24^{\circ} \mathrm{S}\right)$ during EN 1997/98, but during LN 1999 due to elevated abundances of the grazing black sea urchin Tetrapygus niger (Vega et al. 2005) and overgrazing, which resulted in areas without the former kelp, called "barren ground". The latter is dominated by sea urchins and calcareous crustose red algae (Vásquez 1992).

Constant sea urchin grazing may alter sporophyte morphology, and thus modulate the habitat structure available for macrozoobenthic and fish communities (Vásquez and Vega 2004). Two morphotypes of L. trabeculata have been described: (1) a shrub form, with the total mass distributed among many stipes with high flexibility and (2) an arborescent form, where the total mass is allocated to only very few stipes with limited flexibility (Vásquez 1992; Vásquez 1993a). The shrub form is favoured by minor grazing due to high plant abundances and a strong whiplash effect on herbivores (Vásquez 1992; Vásquez and Buschmann 1997). In contrast, wave action and currents selectively affect the arborescent form, as its lower flexibility causes a higher chance of dislodgement (Vásquez and Buschmann 1997). For M. integrifolia differences in the blade morphology have been related to wave exposure (Hurd et al. 1997). It has been stated that distinct morphotypes may alter the associated invertebrate and fish assemblages (Vásquez 1991).

Our study aims to relate different habitat structures of a $M$. integrifolia kelp bed, a dense L. trabeculata kelp bed and patchily distributed $L$. trabeculata colonizing barren ground with the associated benthic macroinvertebrate community, focussing on key species, which possibly modulate predator-herbivore-kelp interactions, such as sea urchins and sea stars.

\section{Materials and methods}

Study site

The study was conducted in Chipana $\left(21^{\circ} \mathrm{S} 71^{\circ} \mathrm{W}\right)$, located $170 \mathrm{~km}$ south of Iquique city (northern Chile) (Fig. 1). The area is a coastal upwelling site (Fuenzalida 1992; Palma et al. 2006), composed of a $4 \mathrm{~km}$ long sandy bay exposed to the northwest with some shallow rocky areas. The latter provide substrate for extended kelp beds composed monospecifically of either $L$. trabeculata or $M$. integrifolia. Three different habitats, a $M$. integrifolia kelp bed, a dense $L$. trabeculata bed, and $L$. trabeculata patches colonizing a barren ground were studied (Fig. 1).

Habitat features and macroinvertebrate communities

Seasonal sampling was carried out between spring 2005 and winter 2006, always choosing days with calm sea conditions. A total of 60 independent sampling units $(10 \mathrm{~m} \times 1 \mathrm{~m}$ each, separated by $\geq 17 \mathrm{~m}$ ) located along three replicated transects (five replicates per transect) for each habitat were assessed. Within sampling units the same SCUBA diver counted all sporophytes of M. integrifolia and L. trabeculata
Fig. 1 Map showing the location of the studied (open square) Macrocystis integrifolia kelp bed, the (open inverted triangle) Lessonia trabeculata kelp bed and (open triangle) L. trabeculata patches on the barren ground off Chipana (northern Chile)

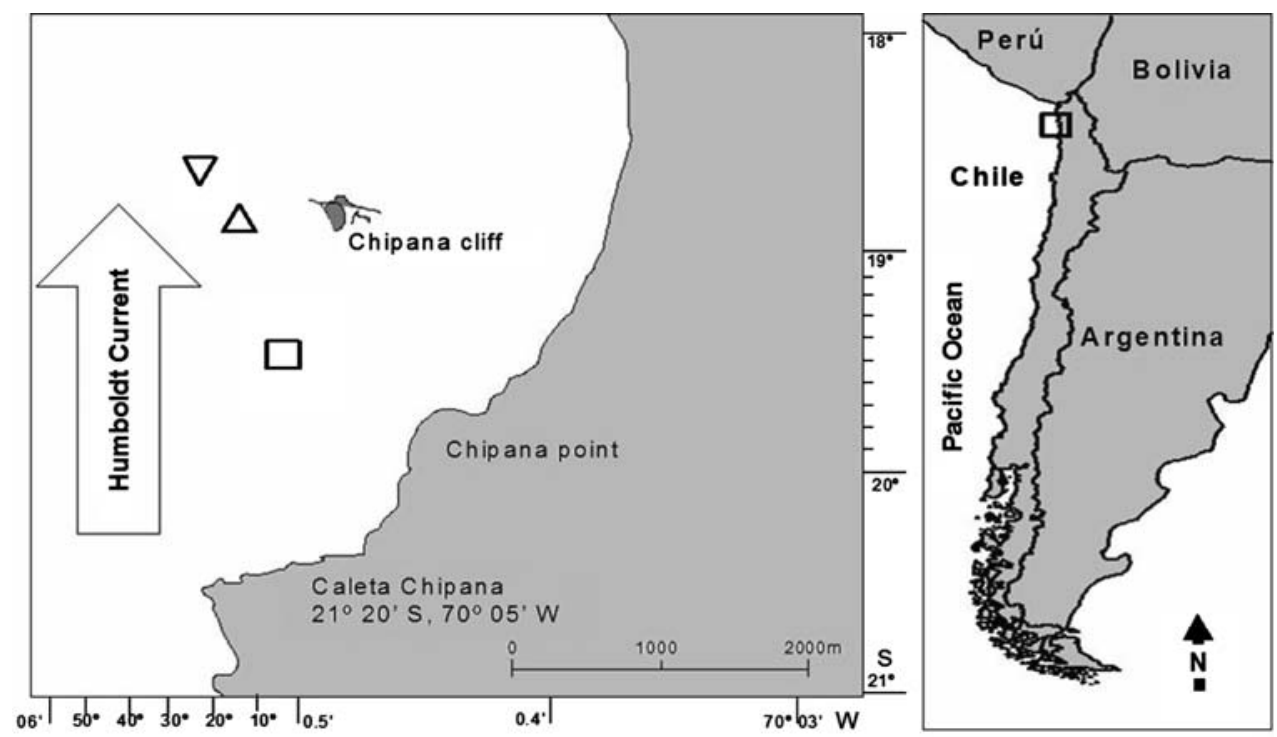


present. Sporophytes with a single holdfast or an evident fusion, which did not allow discriminate one holdfast from the other by underwater observation, were considered as individual plants. Depth and substrate type were recorded as "bare rock", "boulder", and "sand" dominated following Godoy (2000). Furthermore, the visible macroscopic epifauna was counted in situ from squares $(1 \mathrm{~m} \times 1 \mathrm{~m}$ each, $n=180$ ) haphazardly placed on the substratum between individual sporophytes. Total values were standardized to $10 \mathrm{~m}^{2}$. Additionally, a total of 36 sporophytes (9 per sampling day) were collected and analysed in the laboratory to individually measure total plant length, maximal holdfast diameter, stipe number, number of dichotomies per stipe, frond width and total drained wet mass.

\section{Statistical analysis}

Since data were not normally distributed (KolmogorovSmirnow and Shapiro-Wilk's test), a non-parametric Kruskall-Wallis test was applied (Zar 1996). Morphological variables were evaluated with Spearman's correlation analysis. All analyses were performed using the Statistica 6.0 software. Invertebrate assemblages were assessed using univariate biodiversity indices such as species richness $(r$ Margalef: $(S-1) / \log (N))$, Shannon-Wiener Index $\left(H^{\prime}\right.$, $\log e$ ), and Pielou's evenness $\left(J^{\prime}\right)$ calculated with the PRIMER 6.0 software.

Morphological variables and invertebrate community structures were examined by principal component analysis (PCA) using cumulated data of the three habitats. Since PC1 and PC2 were uncorrelated, a multivariate analysis of variance (MANOVA) was performed comparing scores for PC1 and PC2 among habitats. For the invertebrate fauna the same analyses were carried out after removing rare taxa or those found only in one habitat. Finally, PC scores from plant morphology and invertebrate fauna were examined for multiple correlations, Eigenvectors up to 0.35 were considered to be strong.

\section{Results}

Depth distributions of the three kelp habitats differed; M. integrifolia forms a bed between 4 and $6 \mathrm{~m}$, the dense L. trabeculata bed was recorded between 7 and $12 \mathrm{~m}$, while the patches of $L$. trabeculata colonize the barren ground area between 5 and $8 \mathrm{~m}$ depth. Significant differences (KruskalWallis test $H_{2,175}=21.9, P<0.05$ ) were recorded for the substrate composition. The $M$. integrifolia habitat is mainly composed of boulders (54\%) followed by bare rock (28\%) and sand (17\%). In contrast, the dense L. trabeculata bed mainly contains bare rock (49\%), boulders (38\%) and sand (12\%), while L trabeculata patches grow predominantly on bare rock $(51 \%)$, boulders $(17 \%)$ and sand $(31 \%)$. Sporophyte densities also showed significant differences (Kruskal-Wallis test $H_{2,175}=11.8, P<0.05$ ) between the three habitats. The $L$. trabeculata bed provided higher abundances ( $40.0 \pm 18.0$ individuals $10 \mathrm{~m}^{-2}$ ) compared to the $M$. integrifolia bed $\left(29.9 \pm 23.1\right.$ individuals $\left.10 \mathrm{~m}^{-2}\right)$ and the $L$. trabeculata patches $\left(28.1 \pm 25.0\right.$ individuals $\left.10 \mathrm{~m}^{-2}\right)$.

Morphological variables of macroalgae significantly differed between habitats; Individual $M$. integrifolia and plants of the dense $L$. trabeculata bed have a dissimilar stipe number (Kruskal-Wallis test, $H_{2,98}=25.7, P<0.01$ ), number of dichotomies per stipe (Kruskal-Wallis test, $H_{2,68}=32.5, P<0.01$ ), frond width (Kruskal-Wallis test $\left.H_{2,98}=24.3, P<0.01\right)$ and total plant length $\left(H_{2,98}=53.6\right.$, $P<0.01$ ) (Fig. 2a-d). No significant difference was found for maximum holdfast diameter (Kruskal-Wallis test, $\left.H_{2,98}=0.71, P=0.72\right)$ and wet mass (Kruskal-Wallis test $H_{2,86}=3.31, P=0.19$ ) (Fig. 2 e, f). $L$. trabeculata plants from patches intercepting barren ground are characterized by significantly shorter sporophytes with higher stipe numbers (Fig. 2 a, d). The observed patterns between M. integrifolia plants and specimens of the dense $L$. trabeculata bed were recorded during all four seasons, except for the stipe number, which did not differ during spring (Kruskal-Wallis test, $H_{2,21}=2.40, P>0.05$ ) and winter (Kruskal-Wallis test $\left.H_{2,23}=5.14, P>0.05\right)$.

Morphological relations

Maximum holdfast diameter of $M$. integrifolia correlates positively with wet mass $(r=0.62, P<0.01)$ and stipe number $(r=0.41, P<0.05)$ (Table 1$)$; furthermore stipe number was correlated with wet mass $(r=0.57, P<0.05)$. For plants from the L. trabeculata bed, all morphological variables showed a significant positive correlation with the exception of stipe number in relation to total plant length (Table 1). Strong relations were found between maximum holdfast diameter and wet mass $(r=0.73, P<0.05)$, between maximum holdfast diameter and total plant length $(r=0.6, P<0.05)$; as well as between total plant length and wet mass $(r=0.66, P<0.05)$. In contrast, the plants of L. trabeculata from the patches growing in the barren ground area only showed a significant positive relation between maximum holdfast diameter and wet mass $(r=0.69, P<0.05)$ as well as with total plant length $(r=0.5, P<0.05)$; and total plant length with wet mass $(r=0.49, P<0.05)$ (Table 1).

The PCA of the combined habitats modelled $95 \%$ of the variation in the first two $\mathrm{PC}$ axes (Table 2). The first axis was mainly influenced (Eigenvectors $>0.35$ ) by maximum holdfast diameter, frond width, stipe number and wet mass. The number of dichotomies, total plant length, wet mass and stipe number were the most important Eigenvectors for 

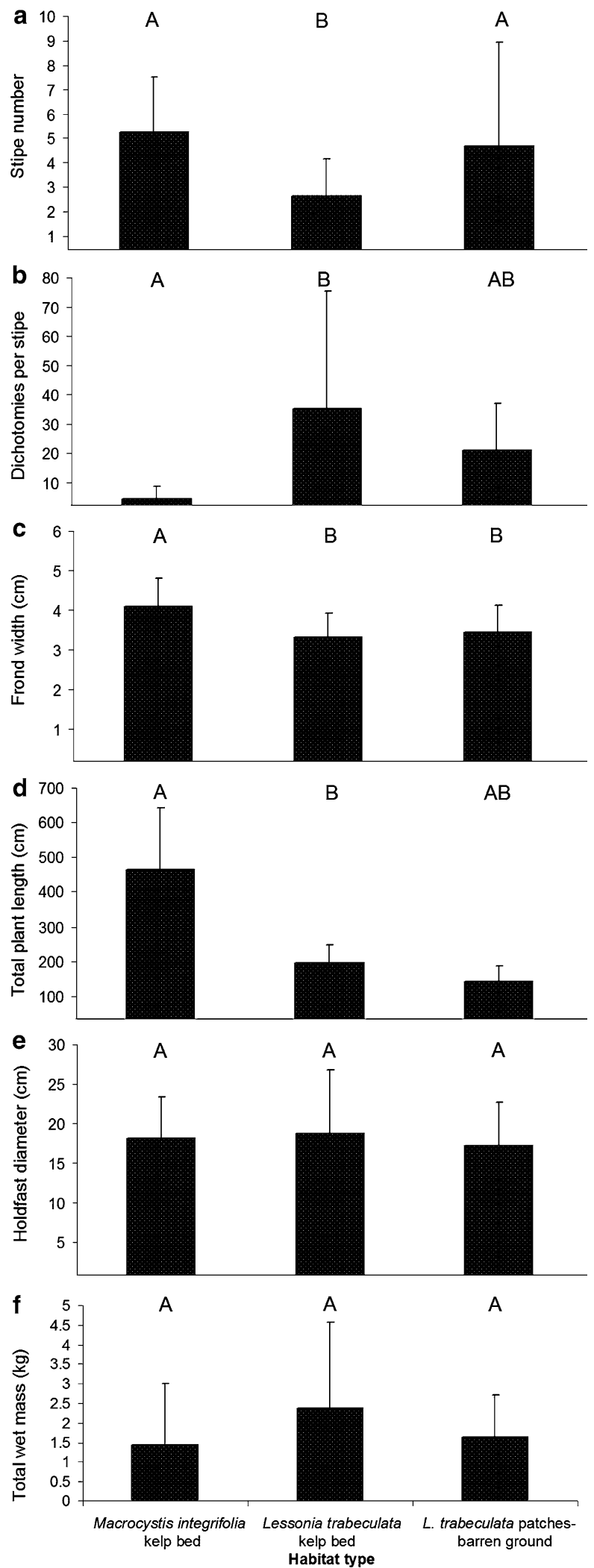

Fig. 2 Morphological variables of Macrocystis integrifolia and Lessonia trabeculata inhabiting three distinct habitats, a stipe number, b dichotomies per stipe, $\mathbf{c}$ frond width, $\mathbf{d}$ total plant length $\mathbf{e}$ holdfast diameter, f total wet mass; (mean $\pm \mathrm{SD}$ ). Bars with distinct letters indicate significant differences (Kruskal-Wallis test, $P<0.05$ )
Table 1 Spearman's Correlation coefficient between morphological variables of Macrocystis integrifolia and Lessonia trabeculata from both, dense bed and patches distributed in barren ground habitats

\begin{tabular}{llll}
\hline Relation & $\begin{array}{l}\text { Macrocystis } \\
\text { integrifolia } \\
\text { kelp bed }\end{array}$ & $\begin{array}{l}\text { Lessonia } \\
\text { trabeculata } \\
\text { kelp bed }\end{array}$ & $\begin{array}{l}\text { Lessonia trabeculata } \\
\text { patches on barren } \\
\text { ground }\end{array}$ \\
\hline MHD-WM & $\mathbf{0 . 6 2}$ & $\mathbf{0 . 7 3}$ & $\mathbf{0 . 6 9}$ \\
MHD-TPL & 0.23 & $\mathbf{0 . 6}$ & $\mathbf{0 . 5}$ \\
MHD-SN & $\mathbf{0 . 4 1}$ & $\mathbf{0 . 4 2}$ & 0.22 \\
TPL-WM & 0.34 & $\mathbf{0 . 6 6}$ & $\mathbf{0 . 4 9}$ \\
SN-WM & $\mathbf{0 . 5 7}$ & $\mathbf{0 . 4 9}$ & 0.23 \\
SN-TPL & 0.24 & 0.18 & -0.27 \\
\hline
\end{tabular}

Significant $(P<0.05)$ relations in bold

$M H D$ maximum holdfast diameter, $W M$ wet mass, $T P L$ total plant length, $S N$ stipe number

Table 2 Results of principal components analyses (PCA) based on morphological variables of Macrocystis integrifolia and Lessonia trabeculata each from both, dense bed and patches distributed in a barren ground habitat

\begin{tabular}{lcc}
\hline PCA axis & PC1 & PC2 \\
\hline Eigenvalue & 4.24 & 1.44 \\
Proportion of variation & 70.78 & 24.0 \\
Cumulative variation & 70.8 & 94.8 \\
\hline Eigenvectors & & \\
No stipes & $-\mathbf{0 . 4 2}$ & -0.37 \\
Wet mass & -0.41 & $\mathbf{0 . 3 9}$ \\
Holdfast diameter & $-\mathbf{0 . 4 8}$ & 0.07 \\
Total plant length & -0.32 & $-\mathbf{0 . 5 8}$ \\
No dichotomy per stipe & -0.31 & $\mathbf{0 . 6 1}$ \\
Frond width & $\mathbf{- 0 . 4 8}$ & -0.08 \\
\hline
\end{tabular}

For all axes with Eigenvalues $>1.0$ the later proportion of variation modelled, cumulative variation modelled and Eigenvectors (variable loadings) are indicated. Eigenvectors with the strongest loadings $(>0.35)$ in bold

PC2 (Table 2). The two first PCs showed significant differences between the three studied habitats (one-way ANOVA, $P<0.05$, Table 3), indicating different habitat structures. Number of dichotomies per stipe, wet mass and holdfast diameter were the morphological variables, which mainly explained the variability of specimens from the dense $L$. trabeculata kelp bed, as well as the L. trabeculata patches on the barren ground, whereas the morphological variability of $M$. integrifolia was mainly caused by total plant length, stipe number, and frond width (Fig. 3).

Macroinvertebrate community

A total of 22 epifaunal macroinvertebrate species, visible during the dive survey, was recorded during the study period. In terms of abundance the ascidian Piura chilensis, 
Table 3 One-way ANOVA values from morphological variables of each habitat of the first two principal components

\begin{tabular}{lll}
\hline & PC1 & PC2 \\
\hline Effect & Kelp type & Kelp type \\
SS & 33.4 & 86.24 \\
Dreg freedom & 2.0 & 2 \\
MS & 16.7 & 43.12 \\
$F$ & 4.2 & 91.42 \\
$P$ & $<0.01$ & $<0.01$ \\
Macrocystis integrifolia kelp bed & $0.75 \pm 0.37$ & $-1.36 \pm 0.13$ \\
Lessonia trabeculata kelp bed & $-0.76 \pm 0.36$ & $0.99 \pm 0.13$ \\
L. trabeculata patches & $0.03 \pm 0.36$ & $0.33 \pm 0.13$ \\
$\quad$ on barren ground & &
\end{tabular}

Mean \pm SE values from the PC scores 1 and 2 are shown by habitat type

the mussel Aulacomya ater and the black sea urchin T. niger numerically dominated the three habitats (Table 4). The $M$. integrifolia kelp bed community was mainly composed of Tunicates and Cnidarians, whereas the L. trabeculata kelp bed showed a high percentage of Molluscs and Echinoderms (Table 4). The L. trabeculata patches on barren ground were mainly dominated by Echinoderms and Tunicates (Table 4). Here, the highest species richness $(S=18, \quad r=4.01)$, diversity $\left(H^{\prime}=2.01\right)$ and evenness $\left(J^{\prime}=0.69\right)$ were recorded; however, the total individual number was comparatively low (Table 4). The dense L. trabeculata bed showed a similar species richness $(S=14$, $r=2.64)$, diversity and evenness $\left(H^{\prime}=1.35 ; J^{\prime}=0.51\right)$, compared to the $M$. integrifolia bed $(S=15, r=2.78$; $H^{\prime}=1.68 ; J^{\prime}=0.62$ ) (Table 4).

All three habitats are inhabited by high abundances of echinoderms, such as the sea urchins T. niger and Loxechinus albus as well as the carnivorous sun star Heliaster helianthus and the black sea star Luidia magellanica (Table 4). The two sea urchin species and the sun star were significantly more abundant in the $M$. integrifolia bed
(Kruskal-Wallis test, $H_{3,240}=29.3, P<0.01$ ), compared to the L. trabeculata bed (Kruskal-Wallis test, $\mathrm{H}_{3,240}=57.4$, $P<0.01)$, and to the patchily colonized barren ground (Kruskal-Wallis test, $H_{3,220}=38.3, P<0.01$ ) where the sea urchin species numerically dominated the sea stars.

The $T$. niger was significantly more abundant in the barren ground habitat intercepted with L. trabeculata patches and the $M$. integrifolia bed compared to the dense L. trabeculata bed (Kruskal-Wallis test, $H_{2,175}=6.04, P<0.05$ ), while the red sea urchin L. albus was significantly more abundant in both L. trabeculata habitats (Kruskal-Wallis test, $H_{2,175}=13.4$, $P<0.01)$. The sun star $H$. helianthus was significantly more abundant in the $M$. integrifolia bed compared with the other two habitats (Kruskal-Wallis test, $\mathrm{H}_{2,175}=35.3, P<0.01$ ), while the abundance of the black sea star L. magellanica did not show any significant difference between habitats (Kruskal-Wallis test, $H_{2,175}=3.06, P=0.21$ ).

Results of the PCA confirm similar trends of different dominating species in the distinct habitats. For the combined habitats the PCA modelled $23 \%$ of the invertebrate variability on the first two PC axes (Table 5). High species scores in PC1 were associated with $T$. niger, $T$. tridentata and A. alicemartinae, whereas high species scores on PC2 were linked with $H$. helianthus, $P$. chilensis and A. chilensis. Significant differences between the invertebrate fauna of the three habitats were found for the first two PCs (ANOVA, $P<0.05$, Table 6).

Multiple correlations between PC scores from plant morphology and invertebrate fauna revealed that morphological variables from PC2 (number of dichotomies per stipe, total plant length, wet mass and stipe number) are significantly related to the fauna from $\mathrm{PC} 1$ (A. alicemartinae, $T$. tridentata and T. niger) and PC2 (A. chilensis, H. helianthus and $P$. chilensis) (Table 7). A high correlation value between PC1 invertebrates and PC2 plant morphology $(R=0.40$, $P<0.01$, Table 7) indicates that morphological variables (i.e. number of dichotomy per stipe, total plant length, wet mass and stipe number, Table 2) drive the invertebrate
Fig. 3 Scores of kelp habitats for the first two principal component (Factor) axes based on principal components analysis of morphological variables from $M$. integrifolia kelp bed (open square), L. trabeculata kelp bed (open inverted triangle) and L. trabeculata patches on barren ground (open triangle). a Projection of the Eigenvectors of morphological variables, b projection of the cases from each habitat type
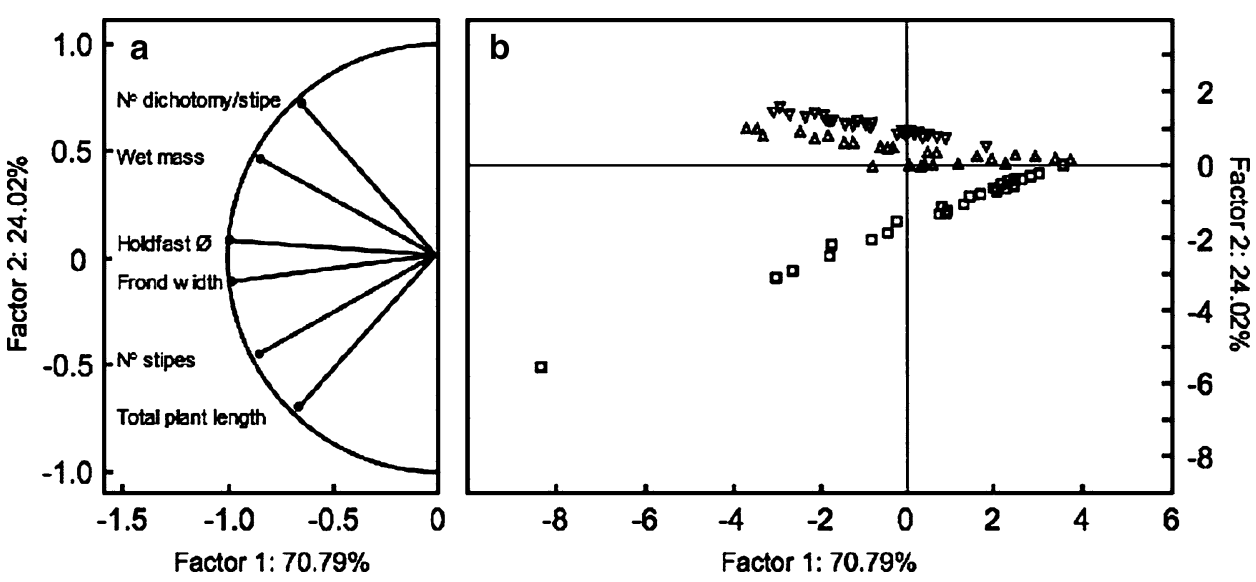
Table 4 Abundance (individuals $10 \mathrm{~m}^{-2}$ ) of macroinvertebrates associated with a Macrocystis integrifolia bed, Lessonia trabeculata bed and patchily distributed L. trabeculata on a barren ground habitat off Chipana (mean \pm SD)

\begin{tabular}{|c|c|c|c|c|c|c|c|}
\hline & & \multicolumn{2}{|c|}{$\begin{array}{l}\text { Macrocystis } \\
\text { integrifolia kelp bed }\end{array}$} & \multicolumn{2}{|c|}{$\begin{array}{l}\text { Lessonia } \\
\text { trabeculata kelp bed }\end{array}$} & \multicolumn{2}{|c|}{$\begin{array}{l}\text { Lessonia trabeculata } \\
\text { patches-barren ground }\end{array}$} \\
\hline & & $N$ & $\%$ & $N$ & $\%$ & $N$ & $\%$ \\
\hline Cnidaria & & 45.3 & 29.4 & 2.1 & 1.7 & 8.1 & 11.8 \\
\hline \multirow[t]{2}{*}{ Anthozoa } & Anemonia alicemartinae & $42.1 \pm 55.2$ & 27.4 & $2.1 \pm 6.9$ & 1.7 & $5.9 \pm 16.1$ & 8.6 \\
\hline & Anthothoe chilensis & $3.2 \pm 20.7$ & 2.1 & $0.0 \pm 0.0$ & 0.0 & $2.2 \pm 6.1$ & 3.2 \\
\hline Mollusca & & 26.4 & 17.1 & 75.6 & 60.0 & 10.2 & 14.9 \\
\hline Bivalvia & Aulacomya ater & $0.0 \pm 0.0$ & 0.0 & $69.6 \pm 136.1$ & 55.5 & $0.0 \pm 0.0$ & 0.0 \\
\hline \multirow[t]{8}{*}{ Gastropoda } & Concholepas concholepas & $0.16 \pm 0.73$ & 0.1 & $0.9 \pm 4.8$ & 0.7 & $1.2 \pm 2.8$ & 1.7 \\
\hline & Crassilabrum crassilabrum & $2 \pm 15.4$ & 1.3 & $0.0 \pm 0.0$ & 0.0 & $0.0 \pm 0.0$ & 0.0 \\
\hline & Fissurella cumingi & $0.0 \pm 0.0$ & 0.0 & $0.0 \pm 0.0$ & 0.0 & $0.1 \pm 0.5$ & 0.1 \\
\hline & Fissurella latimarginata & $0.9 \pm 2.8$ & 0.6 & $0.2 \pm 0.9$ & 0.2 & $1.9 \pm 6.1$ & 2.8 \\
\hline & Priene rude & $0.0 \pm 0.0$ & 0.0 & $0.2 \pm 1.4$ & 0.2 & $2.7 \pm 11.8$ & 3.9 \\
\hline & Tegula atra & $0.0 \pm 0.0$ & 0.0 & $0.2 \pm 0.7$ & 0.2 & $1.4 \pm 6.2$ & 2.0 \\
\hline & Tegula tridentata & $23.3 \pm 102.9$ & 15.1 & $4.2 \pm 20$ & 3.3 & $2.6 \pm 11.6$ & 3.8 \\
\hline & Thais chocolata & $0.0 \pm 0.0$ & 0.0 & $0.0 \pm 0.0$ & 0.0 & $0.2 \pm 1.3$ & 0.3 \\
\hline Polyplacophora & Chiton granulosus & $0.0 \pm 0.0$ & 0.0 & $0.0 \pm 0.0$ & 0.0 & $0.1 \pm 0.4$ & 0.1 \\
\hline Crustacea & & 0.5 & 0.3 & 0.3 & 0.2 & 0.4 & 0.6 \\
\hline \multirow[t]{4}{*}{ Brachyura } & Cancer setosus & $0.4 \pm 1.6$ & 0.3 & $0.3 \pm 1.8$ & 0.2 & $0.2 \pm 0.7$ & 0.3 \\
\hline & Cancer coronatus & $0.1 \pm 0.5$ & 0.1 & $0.0 \pm 0.0$ & 0.0 & $0.0 \pm 0.0$ & 0.0 \\
\hline & Paranxanthus barbiger & $0.03 \pm 0.3$ & 0.0 & $0.0 \pm 0.0$ & 0.0 & $0.0 \pm 0.0$ & 0.0 \\
\hline & Taliepus dentatus & $0.0 \pm 0.0$ & 0.0 & $0.0 \pm 0.0$ & 0.0 & $0.2 \pm 0.8$ & 0.3 \\
\hline Echinodermata & & 27.3 & 17.7 & 28.5 & 22.6 & 30.7 & 44.8 \\
\hline \multirow[t]{2}{*}{ Echinoidea } & Loxechinus albus & $5.7 \pm 10.7$ & 3.7 & $15.3 \pm 22.9$ & 12.2 & $11.8 \pm 25.4$ & 17.2 \\
\hline & Tetrapygus niger & $17.1 \pm 43.4$ & 11.1 & $11.5 \pm 18.3$ & 9.1 & $17.4 \pm 29.7$ & 25.4 \\
\hline \multirow[t]{3}{*}{ Asteroidea } & Heliaster helianthus & $3.9 \pm 4.9$ & 2.5 & $1.1 \pm 1.8$ & 0.9 & $0.5 \pm 1.2$ & 0.7 \\
\hline & Luidia magellanica & $0.5 \pm 1.6$ & 0.3 & $0.5 \pm 1.1$ & 0.4 & $0.9 \pm 1.8$ & 1.3 \\
\hline & Strichaster striatus & $0.1 \pm 0.4$ & 0.1 & $0.1 \pm 0.4$ & 0.1 & $0.1 \pm 0.9$ & 0.1 \\
\hline Tunicata & & 54.4 & 35.3 & 19.4 & 15.4 & 19.2 & 28.0 \\
\hline Ascidacea & Piura chilensis & $54.4 \pm 115.3$ & 35.3 & $19.4 \pm 42.2$ & 15.4 & $19.2 \pm 73.2$ & 28.0 \\
\hline S & & 15 & & 14 & & 18 & \\
\hline$N$ & & 153.7 & & 135.6 & & 68.8 & \\
\hline$r$ & & 2.78 & & 2.64 & & 4.01 & \\
\hline$H^{\prime}$ & & 1.68 & & 1.35 & & 2.01 & \\
\hline$J^{\prime}$ & & 0.62 & & 0.51 & & 0.69 & \\
\hline
\end{tabular}

Pooled abundances $(N)$ and percentages $(\%)$ are indicated in bold. The lower part of the table provide biodiversity indices; $S$ : total species number, $N$ : total individual number, $r$ : species richness, $H^{\prime}\left(\log\right.$ e): Shannon-Wiener Index, $J^{\prime}$ : evenness

fauna (e.g. A. alicemartinae, T. tridentata and T. niger, Table 5). These species are important components of the M. integrifolia invertebrate fauna (Table 4).

\section{Discussion}

Habitat distribution and structure

The present study compares neighbouring $M$. integrifolia and L. trabeculata kelp beds and a barren ground inter- cepted by $L$. trabeculata patches off Chipana $\left(21^{\circ} \mathrm{S}\right)$. $M$. integrifolia mainly colonizes boulders interrupted by sand patches, whereas the L. trabeculata bed covers primarily solid rock, which is in accordance with sites off northern and central Chile (Vásquez 1993a; Hoffman and Santelices 1997; Vega et al. 2005; Graham et al. 2007). The barrens colonized by patches of $L$. trabeculata may result from the constant shifts of sand $(31 \%)$ in this habitat. The L. trabeculata bed is significantly denser (40 individuals $10 \mathrm{~m}^{-2}$ ), compared to $L$. trabeculata patches ( 28 individuals $10 \mathrm{~m}^{-2}$ ) and the M. integrifolia bed (30 individuals $10 \mathrm{~m}^{-2}$ ). Kelp 
Table 5 Results of principal components analyses (PCA) based on the invertebrate groups of the three studied habitats
For all axes with Eigenvalues $>1.0$ Eigenvalues, proportion of variation modelled, cumulative variation modelled, and Eigenvectors (variable loadings) are given. Eigenvectors with the strongest loadings $>0.35$ in bold

\begin{tabular}{lccccccc}
\hline PC axis & PC1 & PC2 & PC3 & PC4 & PC5 & PC6 & PC7 \\
\hline Eigenvalue & 2.0 & 1.7 & 1.4 & 1.3 & 1.2 & 1.1 & 1.0 \\
Proportion of variation & 12.6 & 10.7 & 8.6 & 7.8 & 7.3 & 7.0 & 6.5 \\
Cumulative variation & 12.6 & 23.3 & 31.8 & 39.7 & 47.0 & 54.0 & 60.5 \\
\hline Eigenvectors & & & & & & & \\
Anemonia alicemartinae & $-\mathbf{0 . 5 1}$ & -0.14 & -0.21 & -0.09 & 0.10 & 0.07 & -0.09 \\
Anthothoe chilensis & 0.01 & $\mathbf{0 . 4 2}$ & -0.22 & 0.12 & 0.23 & 0.10 & -0.31 \\
Aulacomya ater & 0.04 & -0.02 & 0.32 & 0.30 & $-\mathbf{0 . 4 7}$ & -0.15 & -0.10 \\
Cancer setosus & 0.14 & -0.04 & 0.17 & 0.05 & $\mathbf{0 . 3 6}$ & $\mathbf{0 . 4 5}$ & $\mathbf{0 . 4 9}$ \\
Concholepas concholepas & 0.17 & -0.14 & $-\mathbf{0 . 5 6}$ & 0.19 & -0.25 & -0.08 & 0.08 \\
Crassilabrum crassilabrum & -0.02 & 0.33 & 0.03 & -0.30 & -0.25 & $-\mathbf{0 . 3 8}$ & $\mathbf{0 . 5 0}$ \\
Fissurella latimarginata & 0.14 & -0.10 & $-\mathbf{0 . 4 7}$ & 0.27 & -0.07 & 0.03 & $\mathbf{0 . 4 1}$ \\
Heliaster helianthus & -0.18 & $\mathbf{0 . 6 0}$ & -0.06 & -0.09 & -0.12 & -0.15 & 0.03 \\
Loxechinus albus & 0.08 & -0.01 & 0.24 & $\mathbf{0 . 5 5}$ & -0.15 & -0.01 & -0.15 \\
Luidia magellanica & 0.16 & -0.17 & -0.27 & -0.04 & 0.31 & $-\mathbf{0 . 4 6}$ & -0.23 \\
Piura chilensis & 0.13 & $\mathbf{0 . 4 9}$ & -0.11 & 0.17 & 0.16 & 0.25 & -0.14 \\
Priene rude & 0.07 & -0.10 & 0.03 & $-\mathbf{0 . 3 7}$ & -0.27 & $\mathbf{0 . 3 6}$ & -0.05 \\
Stichaster striathus & -0.03 & -0.04 & -0.25 & -0.27 & $-\mathbf{0 . 4 1}$ & 0.35 & -0.28 \\
Tegula atra & 0.07 & -0.15 & 0.16 & -0.27 & 0.23 & -0.24 & -0.13 \\
Tegula tridentata & $-\mathbf{0 . 5 2}$ & -0.03 & -0.05 & 0.14 & 0.07 & 0.03 & 0.13 \\
Tetrapygus niger & $\mathbf{0 . 5 6}$ & -0.09 & 0.00 & 0.20 & -0.02 & -0.02 & 0.05 \\
\hline & & & & & &
\end{tabular}

Table 6 One-way ANOVA values from macroinvertebrate fauna of each habitat of the first two principal components

\begin{tabular}{lll}
\hline & PC1 & PC2 \\
\hline Effect & Kelp type & Kelp type \\
SS & 33.5 & 24.1 \\
Dreg freedom & 2 & 2.0 \\
MS & 16.7 & 12.1 \\
$F$ & 10 & 8.2 \\
$P$ & $<\mathbf{0 . 0 1}$ & $<\mathbf{0 . 0 1}$ \\
Macrocystis integrifolia kelp bed & $-0.87 \pm 0.24$ & $0.69 \pm 0.23$ \\
Lessonia trabeculata kelp bed & $-0.31 \pm 0.24$ & $-0.09 \pm 0.22$ \\
L. trabeculata patches on & $0.53 \pm 0.24$ & $-0.58 \pm 0.22$ \\
$\quad$ barren ground & &
\end{tabular}

$\overline{\text { Mean } \pm \text { SE values from the PC scores } 1 \text { and } 2 \text { are shown by habitat }}$ type

beds were situated in the depth ranges described by Vega et al. (2005) for the maximum abundances of the two respective kelp species.

Significant morphological differences supported by multivariate analysis confirmed different habitat structures. The large arborescent form of $M$. integrifolia, which develops floating canopies, is longer, has wider fronds and more stipes, however less dichotomy compared to L. trabeculata. Differences are also evident between the two L. trabeculata habitats as sporophytes of the patches show shorter, younger plants with many stipes and lower dichotomy
Table 7 Multiples correlations series between PC1 and PC2 scores from habitat morphology and invertebrate fauna $(n=89)$

\begin{tabular}{lcc}
\hline & $\begin{array}{c}\text { PC1 habitat } \\
\text { morphology }\end{array}$ & $\begin{array}{c}\text { PC2 habitat } \\
\text { morphology }\end{array}$ \\
\hline PC1 invertebrate fauna & & \\
Multiple $R$ & -0.07 & 0.40 \\
Multiple R2 & 0.01 & 0.16 \\
$F(1,87)$ & 0.46 & 16.41 \\
$P$ & $\mathrm{NS}$ & $<\mathbf{0 . 0 1}$ \\
\hline PC2 invertebrate fauna & & \\
Multiple $R$ & 0.06 & -0.21 \\
Multiple R2 & 0.00 & 0.05 \\
$F(1,87)$ & 0.27 & 4.21 \\
$P$ & $\mathrm{NS}$ & $<\mathbf{0 . 0 5}$ \\
\hline
\end{tabular}

Significant relations in bold

compared with those of the bed. Here, the plants are larger, older and thus provide less temporal changes in the habitat structure. In conclusion the M. integrifolia bed provides a more homogeneous habitat with persistent complexity compared with $L$. trabeculata beds, where the shrub form of plants with a higher dichotomy does not reach the water surface. The habitat patchily colonized by L. trabeculata is more heterogeneous and shows intermediate complex structure, with short plants but numerous stipes not strongly affected by grazing. 
Associated invertebrate community

The invertebrate epifauna recorded during the dive surveys (22 taxa, Table 4) resembled the one, associated with holdfasts elsewhere in Chile (Godoy 2000; Vásquez et al. 2001) and is characteristic for rocky substrates within northern and central Chilean M. integrifolia and L. trabeculata kelp beds (Vásquez 1993b; Stotz et al. 2003; Graham et al. 2007). The three studied communities showed a high degree of overlapping. Molluscs, echinoderms and crustaceans dominated in species number $(10,5$, and 4 species, respectively); however, contributions were unequally distributed between habitats (Table 4). While the same proportions for molluscs were found by holdfast studies (Godoy 2000; Vásquez et al. 2001), the latter observed a much higher percentage of crustaceans and a much lower percentage of echinoderms (29 and 2\%, respectively).

Dominant functional groups of the resent assemblages were carnivores (gastropods, echinoderms and crustaceans) e.g. the gastropod Concholepas concholepas and the sun star H. helianthus; suspension feeders (bivalves, anthozoans and ascidians) mainly represented by the anthozoan A. alicemartinae, the bivalve $A$. ater and the ascidian P. chilensis, and herbivores (gastropods and echinoderms) such as the two sea urchins L. albus and T. niger, as well as the gastropod Tegula tridentata. The two latter species were also recorded as important grazers in other kelp habitats (Vásquez and Buschmann 1997; Vega et al. 2005; Graham et al. 2007; Table 4). The importance of A. alicemartinae, $T$. niger and $T$. tridentata was also confirmed by high PC1 values, significantly associated with morphological variables such as number of dichotomies per stipe, total plant length, wet mass and stipe number. A. alicemartinae is a carnivorous anemone abundant in $M$. integrifolia kelp beds, especially on rock patches grazed upon by the black sea urchin T. niger (Häussermann and Fösterra 2001). The latter is a conspicuous grazer commonly forming sea urchin fronts (Vásquez and Buschmann 1997) and is feeding mainly on benthos (e.g. on benthic and kelp drift algae) (Contreras and Castilla 1987; Rodríguez 2003). Strong sea urchin grazing is mainly apparent at the M. integrifolia bed margins (M.J. Villegas, personal observation). However, high water motion (Vásquez and Buschmann 1997) together with high abundances of predatory sea stars Heliaster heliathus (M.J. Villegas, personal observation) reduces grazing impact. The omnivorous gastropod T. tridentata consumes the benthic and water column biomass of sporophytes (Graham et al. 2007; M.J. Villegas, personal observation) and benthic herbivores (Vásquez 1993b; Vásquez and Buschmann 1997). Much higher abundances of this snail were recorded in the M. integrifolia kelp bed compared with the L. trabeculata habitats (Table 4). However, the differences may have little impact on the standing stock of the brown algae due to low per capita consumption rates reported (Graham et al. 2007), except when the gastropod population explodes (Tegner and Dayton 1991) or when sporophytes are small (Graham et al. 2007). We suggest a significant interaction of this species with the kelp structure concerning food supply (wet mass) and access to shelter and habitat resource (number of dichotomy per stipe, plant length and stipe number).

\section{Biodiversity}

The monospecifically composed kelp beds showed comparatively low diversity, mainly caused by the dominance of the ascidian $P$. chilensis (in the $M$. integrifolia bed) and the mussel A. ater (only present in the L. trabeculata bed), respectively. On the other hand, the barren ground intercepted by $L$. trabeculata patches was colonized by a more diverse, patchy community. The latter mainly resembled one of the two kelp beds; however, the gastropods Fissurella cumingi and Thais chocolata, the polyplacophoran Chiton granulosus and the crustacean Taliepus dentatus were only recorded in patches (Table 4). Here, kelp plants are subject to strong sea urchin grazing (which is not limited by intense predation due to low abundances of carnivorous sea stars) and dislodgement caused by currents, because kelp patches are exposed and located shallower compared to beds. This constantly provides open space for settlement (confirmed by the presence of young plants all year long). As larvae of different species settle in different seasons (Marín et al. 2001; Marín and Moreno 2002) and the colonizing assemblages follow a successive process until a community is mature, multiple states of community development are co-occurring due to a relaxed competition. This is supported by higher species richness (18 species; $H^{\prime}$ : 2.01; Fig. 4c). Thus, moderate disturbance at intermediate frequency leads to highest diversity supporting the intermediate disturbance hypothesis (Connell 1978) adapted for community structure by Menge and Sutherland (1987). In contrast, dense beds are scarcely impacted and thus show a more homogeneous community with a slightly lower total species number and diversity (L. trabeculata bed: $S: 15, H^{\prime}: 1.68 ; M$. integrifolia bed: $S: 14 ; H^{\prime}: 1.35$; Fig. 4b). In areas strongly (e.g. EN 1982-1983) or frequently disturbed (sea urchin overgrazing) species start to be eliminated by predation or due to the lack of suitable habitat structure, also resulting in low diversity $\left(H^{\prime}=1.37\right.$, for macroscopic invertebrate species on barren ground off northern Chile; value calculated from Graham et al. 2007) (Fig. 4a). This is supported by results of Graham (2004) who observed a reduction of species by more than onethird when the habitat structure changed from a kelp bed formed by many different kelp species to barren deforested areas. 


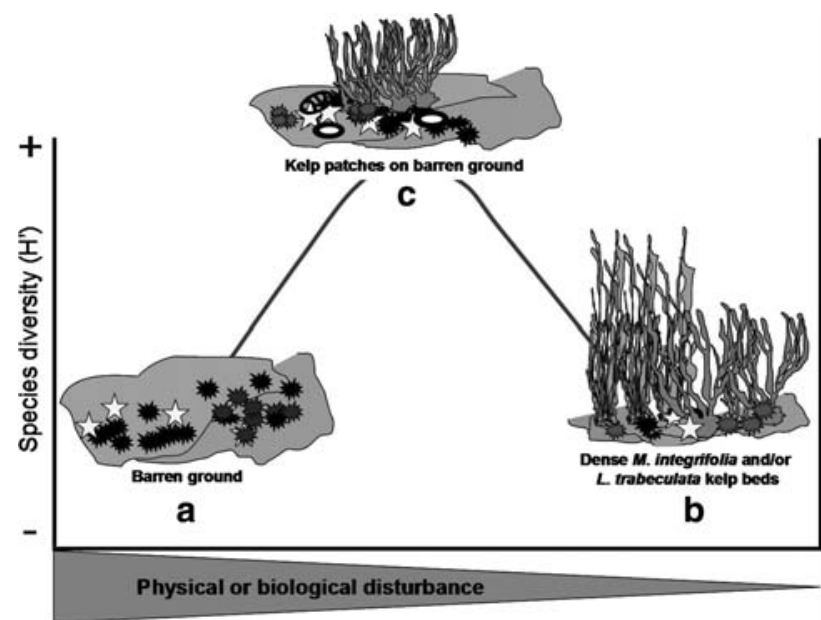

Fig. 4 High levels of physical or biological disturbance (a) are reflected in low species diversity $\left(H^{\prime}\right)$ with only a few pioneer or disturbance tolerant species, as in the case of barren ground; minor disturbance frequency and strength results in well adapted mature communities, however dominated by only a few strong competitors providing a comparatively homogeneous habitat, e.g. dense $M$. integrifolia or $L$. trabeculata beds with relatively low diversity (b); whereas intermediate frequencies and levels of physical or biological disturbance allow a "patchwork" of different successional stages and thus create higher diversity (c), e.g. L. trabeculata patches intercepting barren ground

Our study provides evidence that habitat diversity drives species diversity also in the marine realm, supporting numerous terrestrial studies (e.g. Hart and Horwitz 1991; Tews et al. 2004; Fischer and Lindenmayer 2007). Although we showed that the kelp stands have less richness (but higher abundances; Table 4) than the L. trabeculata patches, clearly the richness of Chilean kelp systems would be much higher than the transition L. trabeculata patches if several kelp habitats were pooled.

Trophic relations and disturbances

On a larger scale kelp habitats of northern Chile comprise a complex food web as different biotopes with their successional stages provide multiple energy pathway scenarios (Graham 2004; Graham et al. 2007) in contrast to simpler kelp systems elsewhere (e.g. Aleuts North Atlantic Japan; Simenstad et al. 1978; Steneck et al. 2002). The elimination of one or a few species may induce alternative energy pathways (Graham 2004; Graham et al. 2007); however, simpler marine systems may show a much higher resilience. The studied M. integrifolia kelp habitat off Chipana revealed significant interactions between important macroinvertebrates components (e.g. A. alicemartinae; T. tridentata and T. niger; Tables 4, 7) and its habitat structure. In comparison, the latter interactions were less important for the L. trabeculata kelp bed.
Disturbance may act on different spatial and temporal scales and possibly affects trophic dynamics of kelp bed habitats. The extremes of the ENSO cycle have been considered as large-scale disturbances, which produce phase shifts between kelp-dominated and sea urchin-dominated states (Tegner and Dayton 1991; Steneck et al. 2002). The strong EN events of 1982-1983 and 1997-1998 affected the physiology of seaweeds (Arntz 1986; Soto 1985; Glynn 1988; Fernández et al. 1999; Godoy 2000; Vásquez and Vega 2004) resulting in mass mortalities, also observed in Chipana (Soto 1985; Urbano Castillo, personal communication). However, during EN 1997-1998 high water temperatures of some sites $\left(23^{\circ} \mathrm{S}\right)$ were buffered by pulses of active upwelling, which prevented total kelp extinction (Vega et al. 2005; Vásquez et al. 2006). Spawning of sea urchins induced by superficial warming resulted in a strong recruitment during 1999 (LN). This, together with topdown effects (i.e. decreasing densities of predatory asteroids) caused strong sea urchin grazing pressure, which diminished the abundance of the remaining $M$. integrifolia (Vega et al. 2005; Vásquez et al. 2006). The upwelling conditions of our study site in Chipana $\left(21^{\circ} \mathrm{S}\right)$ should generate similar processes, affecting the relations between the main macroinvertebrate herbivores and the structure of the M. integrifolia kelp bed.

Our study revealed differences in the morphology of $M$. integrifolia and $L$. trabeculata kelp beds, influencing the composition of their characteristic fauna and its functional relations (i.e. T. niger and T. tridentata). Future work will include in situ experiments and time series analyses to get further insights into effects of physical kelp structures on the distribution, composition and trophic relations of associated invertebrate and fish communities. Further, the importance of functional groups (e.g. feeding guilds) in energy flow patterns of different kelp habitats will be studied.

Acknowledgments We thank Jadhiel Godoy, who assisted MJV during diving excursions in Chipana. We also express our thanks to Urbano Castillo for providing logistics in the field, and the Sindicato de Buzos Mariscadores de Caleta Chipana for permission to work in their management area. Thanks are also due to Raul Espejo, Camilo Villagra, Rosa Vera and Jennisa Avilez who helped with the logistics. We appreciated the valuable comments of two anonymous reviewers who helped in improving this manuscript. This study was funded by the EU project CENSOR (Climate Variability and El Niño Southern Oscillation: Implications for Natural Resources and Management, contract 511071, contribution No 0299) and the Programa Bicentenario de Ciencia y Tecnología CONICYT-CENSOR-RUE02.

\section{References}

Arntz WE (1986) The two faces of El Niño 1982-83. Arch Fish Mar Res/Arch Fisch Meeresforsch 31:1-46 
Arntz WE, Gallardo VA, Gutiérrez D, Isla E, Levin LA, Mendo J, Neira C, Rowe GT, Tarazona J, Wolff M (2006) El Niño and similar perturbation effects on the benthos of the Humboldt, California, and Benguela Current upwelling ecosystems. Adv Geosci 6:243-265

Buschmann AH, Vásquez JA, Osorio P, Reyes E, Filún L, HernándezGonzález MC, Vega A (2004) The effect of water movement, temperature and salinity on abundance and reproductive patterns of Macrocystis spp. (Phaeophyta) at different latitudes in Chile. Mar Biol 145:849-862

Connell JH (1978) Diversity in tropical rain forest and coral reef. Science 199:1302-1310

Contreras S, Castilla JC (1987) Feeding behavior and morphological adaptations in two sympatric sea urchin species in central Chile. Mar Ecol Prog Ser 38:217-224

Fernández E, Córdova C, Tarazona J (1999) Condiciones de la pradera submareal de Lessonia trabeculata en la Isla Independencia durante El Niño 1997-98. In: Tarazona J, Castillo E (eds) El Niño 1997-98 y su impacto en los ecosistemas marino y terrestre. Rev peru biol, Vol. Extraordinario: 47-59 Facultad de Ciencias Biológicas UNMSM

Fischer J, Lindenmayer DB (2007) Landscape modification and habitat fragmentation: a síntesis. Global Ecol Biogeogr 16:265-280

Fuenzalida R (1992) Proceso de surgencia en la Región Norte de Chile, Latitudes $20^{\circ} 30^{\prime} \mathrm{S}-21^{\circ} 45^{\prime} \mathrm{S}$. Invest Cient y Tec Serie: Ciencias del Mar 2:79-104

Glynn PW (1988) El Niño-Southern Oscillation 1982-1983: nearshore population, community, and ecosystem responses. Annu Rev Ecol Syst 19:309-345

Godoy N (2000) Macrocystis integrifolia (Laminariales, Phaeophyta) en el norte de Chile: Distribución espacio-temporal y fauna asociada. Tesis para optar al título de Biólogo Marino. Facultad de Ciencias del Mar, Universidad Católica del Norte, $63 \mathrm{p}$

Graham MH (2004) Effects of local deforestation on the diversity and structure of southern California giant kelp forest food webs. Ecosystems 7:341-357

Graham MH, Vásquez JA, Buschmann AH (2007) Global ecology of the giant kelp Macrocystis: from ecotypes to ecosystems. Oceanogr Mar Biol Annu Rev 45:39-88

Hart DD, Horwitz RJ (1991) Habitat diversity and the species-area relationship: alternative models and tests. In: Bell SS, McCoy ED, Mushinsky HR (eds) Habitat structure: the physical arrangement of objects in space. Chapman \& Hall, London, New York, vol i-xiv, pp 1-438

Häussermann V, Fösterra G (2001) A new species of sea anemone from Chile, Anemonia alicemartinae n. sp. (Cnidaria: Anthozoa). An invader or an indicator of environmental change in shallow water? Org Divers Evol 1:211-224

Hoffman A, Santelices B (1997) Flora marina de Chile Central. Ediciones Universidad Católica de Chile, Santiago, Chile, 434 p

Hurd CL, Stevens CL, Laval BE, Lawrence GA, Harrison PJ (1997) Visualization of seawater flow around morphologically distinct forms of the giant kelp Macrocystis integrifolia from wave-sheltered and exposed sites. Limnol Oceanogr 42(1):156-163

Marín V, Moreno C (2002) Wind driven circulation and larval dispersal: a review of its consequences in coastal benthic recruitment. In: Castilla JC, Largier JL (eds) The oceanography and ecology of the nearshore and bays in Chile. Ediciones Universidad Católica de Chile, pp 47-63

Marín V, Escribano R, Delgado L, Olivares G, Hidalgo P (2001) Nearshore circulation in a coastal upwelling site off the northern Humboldt current system. Cont Shelf Res 21:1317-1329

Menge BA, Sutherland JP (1987) Community regulation: variation in disturbance, competition, and predation in relation to environmental stress and recruitment. Am Nat 130(5):730-757
Palma W, Escribano R, Rosales SA (2006) Modeling study of seasonal and inter-annual variability of circulation in the coastal upwelling site of the El Loa River. Estuarine Coastal Shelf Sci 67:93-107

Pérez A (2006) Dinámica trófica y ensambles de peces submareales asociados a las macroalgas de la costa norte de Chile. Tesis para optar al grado de Magíster en Ciencias del Mar. Facultad de Ciencias del Mar. Universidad Católica del Norte, $112 \mathrm{p}$

Rodríguez S (2003) Consumption of drift kelp by intertidal populations of the sea urchin Tetrapygus niger on the central Chilean coast: possible consequences at different ecological levels. Mar Ecol Prog Ser 251:141-151

Sielfeld W, Vargas M, Berrios V, Aguirre G (2002) Warm ENSO events and their effects on the coastal fish fauna of northern Chile. Invest Mar 30(1):122-124

Simenstad CA, Estes JA, Kenyon KW (1978) Aleuts, Sea Otters, and alternate stable-state communities. Science 200:403-411

Soto R (1985) Efectos del fenomeno del El Niño 1982-83, en ecosistemas de la I Región. Investigaciones pesqueras (Chile) 32:199_ 206

Steneck RS, Graham MH, Bourque BJ, Corbett D, Erlandson JM, Estes JA, Tegner MJ (2002) Kelp forest ecosystems: biodiversity, stability, resilience and future. Environ Conserv 29:436-459

Stotz W, González SA, Caillaux L, Aburto J (2003) Quantitative evaluation of the diet and feeding behaviour of the carnivorous gastropod, Concholepas concholepas (Bruguière, 1789) (Muricidae) in subtidal habitats in the southeastern Pacific upwelling system. J Shell Res 22(1):147-164

Tala F, Edding M, Vásquez J (2004) Aspects of the reproductive phenology of Lessonia trabeculata (Laminariales: Phaeophyceae) from three populations in northern Chile. NZ J Mar Fresh Res 38:255-266

Tegner MJ, Dayton PK (1991) Sea urchins, El Niño, and the long-term stability of southern California kelp forest communities. Mar Ecol Prog Ser 77:49-63

Tews J, Brose U, Grimm V, Tielbörger K, Wichmann MC, Schwager M, Jeltsch F (2004) Animal species diversity driven by habitat heterogeneity/diversity: the importance of keystone structures. J Biogeogr 31:79-92

Vásquez J (1991) Variables morfométricas y relaciones morfológicas de Lessonia trabeculata Villouta \& Santelices, 1986, en una población submareal del norte de Chile. Rev Chile Hist Nat 64:271-279

Vásquez JA (1992) Lessonia trabeculata, a subtidal bottom kelp in northern Chile: a case study for a structural and geographical comparison. In Seeliger U (ed) Coastal plant communities of Latin America. Academic, New York, 392 pp

Vásquez JA (1993a) Patrones de distribución de poblaciones submareales de Lessonia trabeculata (Laminariales: Phaeophyta) en el norte de Chile. Serie Ocasional, Facultad de Ciencias del Mar, Universidad Católica del Norte 2:187-211

Vásquez JA (1993b) Abundance, distributional patterns and diets of main herbivorous and carnivorous species associated to Lessonia trabeculata kelp beds in northern Chile. Serie Ocasional, Facultad de Ciencias del Mar, Universidad Católica del Norte 2:213-229

Vásquez JA, Buschmann AH (1997) Herbivore-kelp interactions in Chilean subtidal communities: a review. Rev Chile Hist Nat $70: 41-52$

Vásquez JA, Vega JMA (2004) El Niño 1997-98 en el norte de Chile: efectos en la estructura y en la organización de comunidades submareales dominadas por algas pardas. In: Avaria S, Carrasco J, Rutllant J, Yáñez E (eds) El Niño-La Niña 1997-2000. Sus Efectos en Chile. CONA, Valparaiso, pp 119-135

Vásquez JA, Véliz D, Pardo LM (2001) Biodiversidad de macroinvertebrados bajo las grandes algas. In: Alveal K, Antezana T (eds) Sustentabilidad de la Biodiversidad. Un Problema Actual, Bases 
Científico Técnicas, Teorizaciones y Perspectivas. Ediciones Universidad de Concepción, Chile, pp 293-308

Vásquez JA, Vega JMA, Buschmann AH (2006) Long term variability in the structure of kelp communities in northern Chile and the 1997-98 ENSO. J Appl Phycol 18:505-519

Vega JMA, Vásquez JA, Buschmann AH (2005) Population biology of the subtidal kelps Macrocystis integrifolia and Lessonia trabecu- lata (Laminariales; Phaeophyceae) in an upwelling ecosystem of northern Chile: interannual variability and El Niño 1997-98. Rev Chile Hist Nat 78:33-50

Zar JH (1996) Biostatistical analysis, 3rd edn. Prentice Hall, Upper Saddle River, New Jersey, 662 p 